\title{
Nonsymbiotic nitrogen fixation in 3-year-old Jeffrey pines and the role of elevated $\left[\mathrm{CO}_{2}\right]$
}

\author{
P.S.J. Verburg, W. Cheng, D.W. Johnson, and D.E. Schorran
}

\begin{abstract}
Increased belowground labile $\mathrm{C}$ inputs under elevated $\left[\mathrm{CO}_{2}\right]$ could stimulate nonsymbiotic $\mathrm{N}_{2}$ fixation, thereby enhancing growth responses of vegetation to elevated $\left[\mathrm{CO}_{2}\right]$ on nutrient-poor sites. To test this hypothesis, nonsymbiotic $\mathrm{N}_{2}$ fixation rates in soils planted with 3-year-old Jeffrey pine (Pinus jeffreyi Grev. \& Balf.) trees grown under 365 and $700 \mu \mathrm{L} \cdot \mathrm{L}^{-1}$ atmospheric $\left[\mathrm{CO}_{2}\right]$ were measured by exposing the soil to ${ }^{15} \mathrm{~N}_{2}$-enriched air for $78 \mathrm{~d}$. Nitrogen fixation rates were estimated by measuring ${ }^{15} \mathrm{~N}$ content of trees and soil. Compared with the ambient $\mathrm{CO}_{2}$ treatment, the elevated $\mathrm{CO}_{2}$ treatment did not affect biomass, $\mathrm{N}$ content, or $\delta^{15} \mathrm{~N}$ of individual plant parts and soils, indicating that elevated $\left[\mathrm{CO}_{2}\right]$ did not stimulate nonsymbiotic $\mathrm{N}_{2}$ fixation. Because belowground $\mathrm{C}$ inputs did not increase under elevated $\left[\mathrm{CO}_{2}\right]$, the initial hypothesis could not be accepted or rejected. The results from the ${ }^{15} \mathrm{~N}_{2}$ labeling study agree with other studies showing that nonsymbiotic $\mathrm{N}_{2}$ fixation is not likely to provide a large input of $\mathrm{N}$ in forest ecosystems. The ${ }^{15} \mathrm{~N}_{2}$ labeling technique was promising for studying $\mathrm{N}_{2}$ fixation in plant-soil systems, but the preliminary nature of this study did not allow for firm conclusions with regard to the effects of elevated $\left[\mathrm{CO}_{2}\right]$.
\end{abstract}

Résumé : L'augmentation des apports de $\mathrm{C}$ labile dans le sol en présence d'une concentration élevée de $\mathrm{CO}_{2}$ pourrait promouvoir la fixation non symbiotique de $\mathrm{N}_{2}$ et par conséquent accroître la réponse en croissance de la végétation à une concentration élevée de $\mathrm{CO}_{2}$ sur les sites pauvres en nutriments. Pour tester cette hypothèse, nous avons mesuré le taux de fixation non symbiotique de $\mathrm{N}_{2}$ dans des sols où avaient été plantés des pins de Jeffrey (Pinus jeffreyi Grev. \& Balf.) âgés de 3 ans et cultivés en présence de concentrations de $\mathrm{CO}_{2}$ atmosphérique de 365 et $700 \mu \mathrm{L} \cdot \mathrm{L}^{-1}$ en exposant le sol à de l'air enrichie avec ${ }^{15} \mathrm{~N}_{2}$ pendant $78 \mathrm{j}$. Le taux de fixation de $\mathrm{N}$ a été estimé en mesurant le contenu en ${ }^{15} \mathrm{~N}$ dans les arbres et le sol. Comparativement à la concentration ambiante de $\mathrm{CO}_{2}$, la concentration élevée de $\mathrm{CO}_{2}$ n'a pas affecté la biomasse, le contenu en $\mathrm{N}$ et la valeur de $\delta^{15} \mathrm{~N}$ ni dans le sol, ni dans les différentes parties des plants, indiquant que la concentration élevée de $\mathrm{CO}_{2}$ n'a pas favorisé la fixation non symbiotique de $\mathrm{N}_{2}$. L'hypothèse de départ ne peut être ni confirmée, ni infirmée étant donné que les apports de $\mathrm{C}$ dans le sol n'ont pas augmenté avec une concentration élevée de $\mathrm{CO}_{2}$. Les résultats de l'expérience de marquage avec ${ }^{15} \mathrm{~N}_{2}$ concordent avec ceux des autres études qui montrent qu'il est peu probable que la fixation non symbiotique de $\mathrm{N}_{2}$ fournisse un apport significatif de $\mathrm{N}$ dans les écosystèmes forestiers. L'utilisation de $\mathrm{N}_{2}$ marqué est une technique prometteuse pour étudier la fixation de $\mathrm{N}_{2}$ dans les systèmes plantes-sol mais la nature préliminaire de cette étude ne permet pas de tirer de conclusions fermes concernant les effets d'une concentration élevée de $\mathrm{CO}_{2}$.

[Traduit par la Rédaction]

\section{Introduction}

Over the past few decades, several studies have shown $\mathrm{N}$ accretion rates in forest soils that are larger than what can be expected based on atmospheric inputs (Binkley et al. 2000). Some of these anomalously high $\mathrm{N}$ accumulation rates have been ascribed to nonsymbiotic $\mathrm{N}_{2}$ fixation (Vitousek et al.
1983; Bormann et al. 1993; Johnson and Todd 1998). Although there is direct evidence that nonsymbiotic $\mathrm{N}_{2}$ fixation can be an important $\mathrm{N}$ input for some agricultural crops (Chalk 1991), its importance for natural forest ecosystems is still being debated (Binkley et al. 2000). The highest potential $\mathrm{N}_{2}$ fixation rates measured were associated with decaying wood (Aho et al. 1974; Roskoski 1980; Crawford et al.

Received 5 October 2003. Accepted 20 April 2004. Published on the NRC Research Press Web site at http://cjfr.nrc.ca on 6 October 2004.

P.S.J. Verburg ${ }^{1}$ and D.E. Schorran. Division of Earth and Ecosystem Sciences, Desert Research Institute, 2215 Raggio Parkway, Reno, NV 89512, USA.

W. Cheng. Department of Environmental Studies, University of California - Santa Cruz, Santa Cruz, CA 95064, USA.

D.W. Johnson. Department of Environmental and Resource Sciences, Fleischmann Agriculture Building/370, University of Nevada, Reno, NV 89557, USA.

${ }^{1}$ Corresponding author (e-mail: paul.verburg@dri.edu). 
Fig. 1. Configuration of the ${ }^{15} \mathrm{~N}$ labeling system. Although only one pot is shown, all eight labeled pots were connected to the same main and secondary plenums. The ${ }^{15} \mathrm{~N}_{2}$ gas was fed through the top and bottom of each soil container to ensure that ${ }^{15} \mathrm{~N}_{2}$ was distributed throughout the soil. Prior to injecting, the ${ }^{15} \mathrm{~N}_{2}$ gas was fed through a liquid argon trap to condense $\mathrm{N}_{2} \mathrm{O}$, $\mathrm{NH}_{3}$, and $\mathrm{NO}$, but not ${ }^{15} \mathrm{~N}_{2} \cdot \mathrm{SF}_{6}$ samples taken from different parts of the system indicated that complete air mixing throughout the system took less than $3 \mathrm{~h}$.

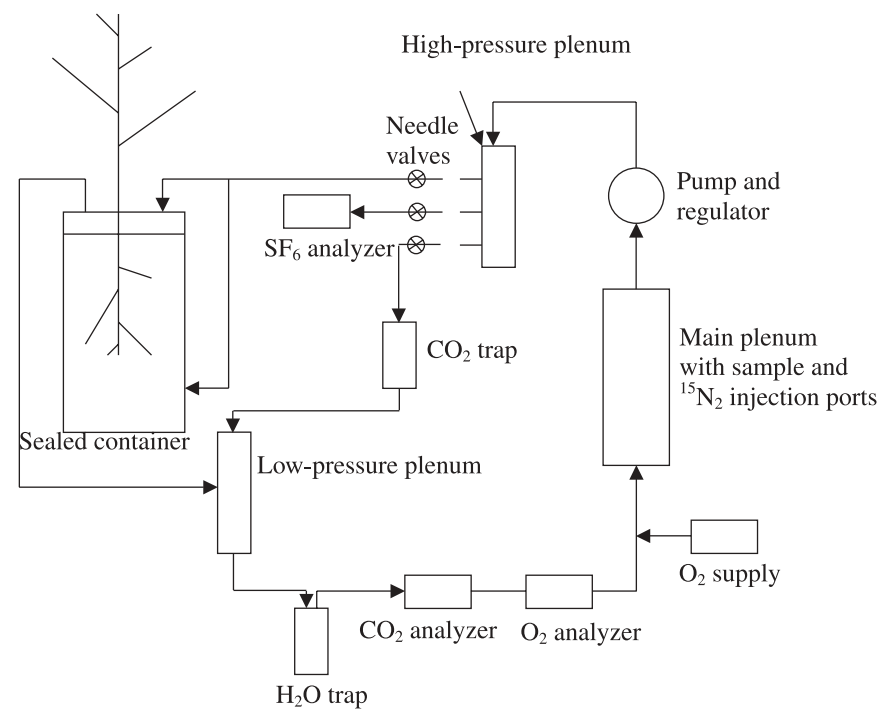

1997). Nonsymbiotic $\mathrm{N}_{2}$ fixation in forest ecosystems could potentially be important in regulating growth responses of vegetation to elevated $\left[\mathrm{CO}_{2}\right]$. Several studies of the effects of elevated $\left[\mathrm{CO}_{2}\right]$ have documented an apparent increase in $\mathrm{N}$ uptake (Johnson et al. 1995, 1997; Zak et al. 2000). This raises interesting questions regarding the source of $\mathrm{N}$ for trees under elevated $\left[\mathrm{CO}_{2}\right]$ : was the additional $\mathrm{N}$ under elevated $\left[\mathrm{CO}_{2}\right]$ derived from: (1) increased mineralization, (2) increased soil exploration, or (3) nonsymbiotic $\mathrm{N}_{2}$ fixation (Bormann et al. 1993)? Hypotheses 1 and 2 have often been used to explain the additional N (Johnson et al. 1997; Zak et al. 2000). Hypothesis 3 is intriguing, as it would be a potential source of $\mathrm{N}$ that would not require extra root exploration, which may be difficult to accomplish in a mature, closed-canopy forest ecosystem, where the soil has been explored by tree roots for many decades. Nitrogen fixation requires a supply of labile C (e.g., Arnone and Gordon 1990; Mulder 1975). Several studies have shown that symbiotic $\mathrm{N}_{2}$ fixation increases under elevated $\left[\mathrm{CO}_{2}\right]$ as a result of increased C availability (e.g., Norby 1987; Arnone and Gordon 1990), but this effect has not been demonstrated for nonsymbiotic $\mathrm{N}_{2}$ fixation. Elevated $\left[\mathrm{CO}_{2}\right]$ can result in increased inputs of labile $\mathrm{C}$ into the soil by increasing root exudation and root litter production (Cheng and Johnson 1998; Van Ginkel and Gorissen 1998; Verburg et al. 1998). This increase in labile $\mathrm{C}$ might stimulate nonsymbiotic $\mathrm{N}_{2}$ fixation and thus $\mathrm{N}$ availability. Since growth responses to elevated $\left[\mathrm{CO}_{2}\right]$ are often limited by low nutrient availability (e.g., Johnson et al. 1995; Oren et al. 2001), nonsymbiotic $\mathrm{N}_{2}$ fixation could enhance biomass production under elevated $\left[\mathrm{CO}_{2}\right]$ by helping to alleviate $\mathrm{N}$ limitation on nutrient-poor sites.
Currently, very few studies exist that have measured nonsymbiotic $\mathrm{N}_{2}$ fixation directly. Potential $\mathrm{N}_{2}$ fixation rates measured using the acetylene-reduction method show much lower $\mathrm{N}_{2}$ fixation rates than estimates based on field studies (Tjepkema 1978; Grant and Binkley 1987; Hendrickson 1990; Barkmann and Schwintzer 1998). In this paper, we investigate the effects of elevated $\left[\mathrm{CO}_{2}\right]$ on nonsymbiotic $\mathrm{N}_{2}$ fixation by exposing the soil of Jeffrey pine (Pinus jeffreyi Grev. \& Balf.) to ${ }^{15} \mathrm{~N}_{2}$-enriched air (Sims et al. 1986; Warembourg 1993; Bremer et al. 1995). We hypothesized that nonsymbiotic $\mathrm{N}_{2}$ fixation is stimulated by elevated $\left[\mathrm{CO}_{2}\right]$, because of enhanced belowground labile $\mathrm{C}$ inputs from root exudation and root litter production.

\section{Materials and methods}

We filled 16 acrylic containers (49 $\mathrm{cm}$ in length, $28 \mathrm{~cm}$ in width; square in cross section) with approximately $35 \mathrm{~kg}$ of soil and planted 3-year-old Jeffrey pine trees. The soil was a mixture of two parts (by vol.) local sandy topsoil $(0-15 \mathrm{~cm}$; frigid Typic Xeropsamment, derived from granitic parent material) and one part organic surface horizon material collected from a local Jeffrey pine stand. Volumetric soil moisture was monitored three times per week using Time Domain Reflectrometry probes installed $5 \mathrm{~cm}$ above the bottom of the containers. If needed, water was added to obtain a soil moisture content of $15 \%$. Moisture content in any of the pots was never below $11 \%$. Prior to the $\mathrm{CO}_{2}$ treatment, the trees were kept at ambient $\left[\mathrm{CO}_{2}\right]$ inside a naturally lit greenhouse at the Desert Research Institute in Reno, Nevada, from May until the end of September. Day : night temperatures inside the greenhouse were $28{ }^{\circ} \mathrm{C}: 23{ }^{\circ} \mathrm{C}$; maximum photon flux density was $1866 \mu \mathrm{mol}$ photons $\cdot \mathrm{m}^{-2} \cdot \mathrm{s}^{-1}$.

Prior to the $\mathrm{CO}_{2}$ treatment, 8 out of 16 containers were covered with acrylic sheets, and openings around the stems were sealed using paraffin wax to separate the shoot from the root compartment. Plumbers' putty was put around the wax to ensure an airtight seal. Three holes were drilled in the top; one for watering, one inlet, and one outlet for ${ }^{15} \mathrm{~N}_{2}$-enriched air. All holes contained a threaded brass fitting sealed with Teflon tape to prevent air leaks. The watering hole was closed by an airtight cap between water additions. An extra air inlet was placed $2 \mathrm{~cm}$ above the bottom of the container to facilitate distribution of the ${ }^{15} \mathrm{~N}$ label to the soil. The top outlet was connected to a pump continuously pulling air through the soil (Fig. 1). Airflow through the bottom inlet was checked regularly to ensure that the airways were not obstructed. The inlets of all pots were connected to a $10-\mathrm{L}$ main plenum, where the ${ }^{15} \mathrm{~N}_{2}$ was added. Two other plenums served as buffers to compensate for pressure changes as a result of the gas additions. Air coming from the low-pressure plenum was sampled hourly for $\left[\mathrm{O}_{2}\right]$ and $\left[\mathrm{CO}_{2}\right]$. Excess $\mathrm{CO}_{2}$ was removed using a soda lime trap. We injected known amounts $99 \%{ }^{15} \mathrm{~N}_{2}$ (Cambridge Isotope Labs, Andover, Massachusetts) at least twice each week during the experiment. The ${ }^{15} \mathrm{~N}_{2}$ gas was delivered at a flow rate of $100 \mathrm{~mL} \cdot \mathrm{min}^{-1}$ to the main 10 -L plenum using a mass flow controller, and the amounts added were based on timed injections. The ${ }^{15} \mathrm{~N}_{2}$ was fed through a liquid argon trap prior to entering the main plenum to condense $\mathrm{N}_{2} \mathrm{O}, \mathrm{NH}_{3}$, and 
Fig. 2. The changes in $\mathrm{SF}_{6}$ concentration and $\delta^{15} \mathrm{~N}$ signal during $20 \mathrm{~d}$ of the $78-\mathrm{d}{ }^{15} \mathrm{~N}$ labeling experiment. Samples for ${ }^{15} \mathrm{~N}_{2}$ were taken manually from the main plenum. Air for $\mathrm{SF}_{6}$ concentrations was sampled automatically from the high-pressure plenum directly connected to an $\mathrm{SF}_{6}$ analyzer (see Fig. 1).

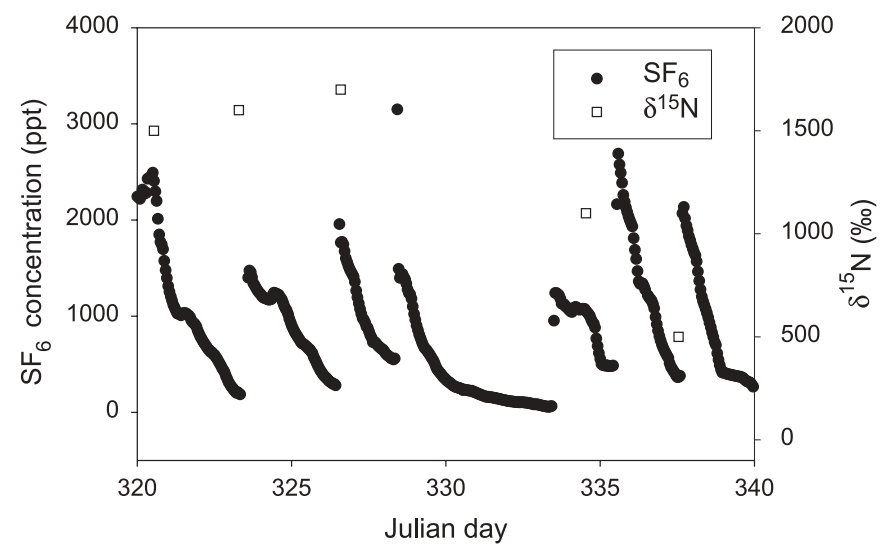

NO, but not ${ }^{15} \mathrm{~N}_{2}$. With every ${ }^{15} \mathrm{~N}_{2}$ injection, we also injected $50-100 \mathrm{~cm}^{3}$ of sulfur-hexa-fluoride $\left(\mathrm{SF}_{6}\right)$ with a concentration of $2.29 \pm 0.04 \mu \mathrm{L} \cdot \mathrm{L}^{-1}$ as a chemically and biologically inert tracer to check for leaks in the system. The $\mathrm{SF}_{6}$ was measured hourly throughout the duration of the experiment using a Varian 3700 gas chromatograph equipped with an electron capture detector. To confirm that all air was well mixed within the system, we measured the $\mathrm{SF}_{6}$ content in different parts of the system including plenum, headspace of the soil containers, and tubing. Complete air mixing typically occurred within $3 \mathrm{~h}$ after each addition. The air was sampled regularly for ${ }^{15} \mathrm{~N}_{2}$ analysis. Extra $\mathrm{O}_{2}$ was added automatically if $\left[\mathrm{O}_{2}\right]$ dropped below $15 \%$. The soil $\left[\mathrm{O}_{2}\right]$ was kept at $15 \%$ during the experiment, and soil $\left[\mathrm{CO}_{2}\right]$ was kept below 3.5\%. The soil $\left[\mathrm{O}_{2}\right]$ was monitored using a Servomex 1440 gas analyzer, and $\mathrm{CO}_{2}$ was monitored using a LiCOR-6262 infrared gas analyzer. For logistical reasons, we could not connect the control containers to a similar closed gas circulation system.

On 27 September, four covered and four uncovered containers were put in a naturally lit growth chamber (Taub et al. 2000) having an atmospheric $\left[\mathrm{CO}_{2}\right]$ of $365 \mu \mathrm{L} \cdot \mathrm{L}^{-1}$. The remaining eight containers were put in a growth chamber operating at $700 \mu \mathrm{L} \cdot \mathrm{L}^{-1}$. Day:night growth temperatures were $25{ }^{\circ} \mathrm{C}: 15{ }^{\circ} \mathrm{C}$. Day length was $12 \mathrm{~h}$. Maximum photosynthetic photon flux density was $1100 \mu \mathrm{mol}$ photons $\cdot \mathrm{m}^{-2} \cdot \mathrm{s}^{-1}$. Light, temperature, and $\left[\mathrm{CO}_{2}\right]$ inside each chamber were monitored automatically and recorded every $15 \mathrm{~min}$. Because of the complexity of the setup, we could not rotate chambers during the experiment to eliminate potential chamber effects. All measured environmental parameters, except for $\mathrm{CO}_{2}$, were identical between the chambers, however, so we assumed that chamber effects were minimal.

After $78 \mathrm{~d}$, the trees were harvested, and biomass was separated into live needles, branches, stems, coarse roots $(>2 \mathrm{~mm})$, and fine roots $(\leq 2 \mathrm{~mm})$. All biomass samples were dried at $70{ }^{\circ} \mathrm{C}$ to constant weight. The soil was separated into bulk and rhizosphere soil. The trees were carefully lifted out of the containers and, after gently shaking, any soil adhering to the intact roots was considered rhizosphere soil (Cheng and Coleman 1990). This method allowed us to col-
Fig. 3. Biomass and $\mathrm{N}$ content of needle, branch, stem, coarse roots (C. root), and fine roots (F. root) of Jeffrey pines. Eight trees were exposed to ambient $\left[\mathrm{CO}_{2}\right]\left(365 \mu \mathrm{L} \cdot \mathrm{L}^{-1}\right)$ for $78 \mathrm{~d}$, while the remaining eight trees were exposed to elevated $\left[\mathrm{CO}_{2}\right]$ $\left(700 \mu \mathrm{L} \cdot \mathrm{L}^{-1}\right)$. Within each $\mathrm{CO}_{2}$ treatment, four trees were exposed to a ${ }^{15} \mathrm{~N}$-enriched soil atmosphere. The ANOVA results showed no significant main nor interactive effects of the labeling and $\mathrm{CO}_{2}$ treatment $(P<0.05)$. Error bars represent standard errors of the mean $(n=4)$.
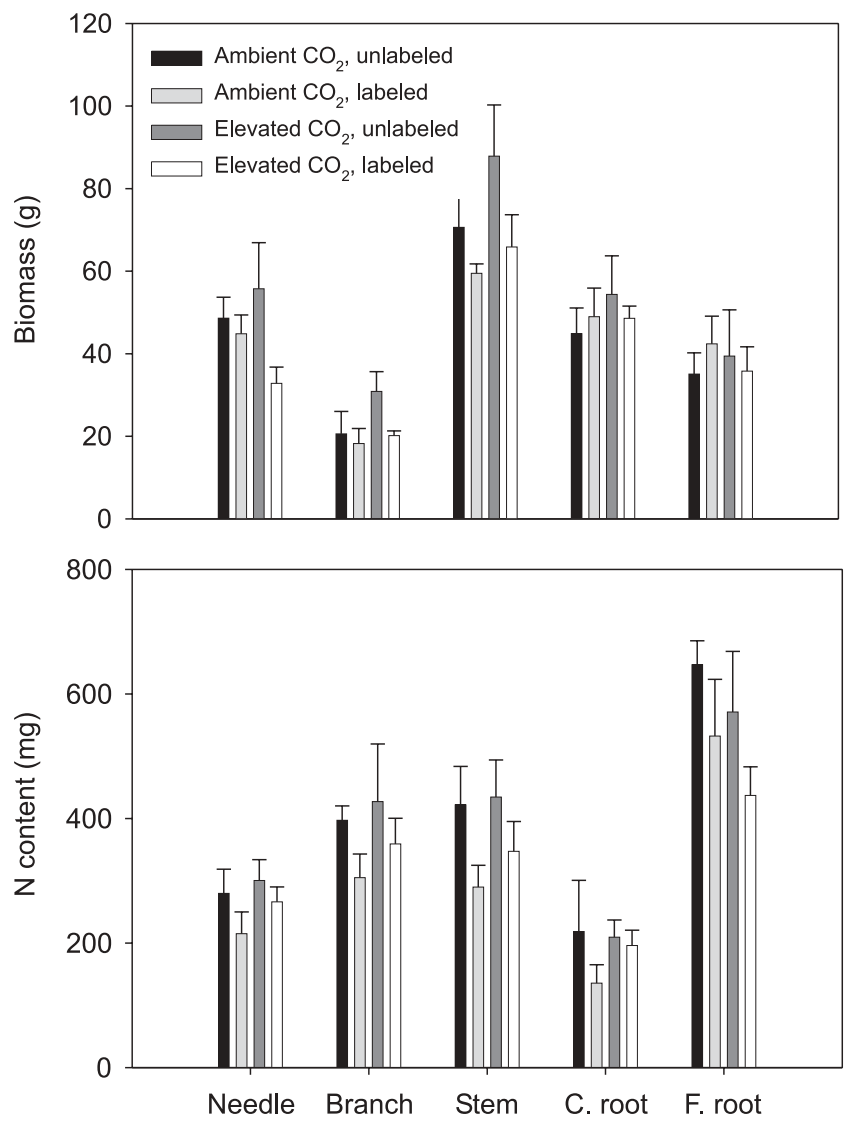

lect soil that had been in immediate contact with the root system. Roots were removed from both bulk and rhizosphere soil by handpicking and rinsed to remove adhering soil particles. Soil samples were homogenized and dried at $70{ }^{\circ} \mathrm{C}$ to constant weight. The ${ }^{15} \mathrm{~N}_{2}$ and total $\mathrm{N}$ content in air, tree, and soil samples were analyzed at the University of California, Davis, using a Europa Scientific "Integra" analyzer (Crewe, UK). The soils were analyzed for total $\mathrm{C}$ using a PerkinElmer $2400 \mathrm{CHN}$ analyzer.

Effects of $\mathrm{CO}_{2}$ on plant and soil $\mathrm{C}, \mathrm{N}$ content, and $\delta^{15} \mathrm{~N}_{2}$ were analyzed by two-way analysis of variance (ANOVA) with "labeled vs. unlabeled" and " $\mathrm{CO}_{2}$ treatment" as main factors using DataDesk version 6.0. Because we assumed that chamber effects were absent, we treated our experiment as a fully replicated design. Main effects were considered to be significant if $P<0.05$.

\section{Results and discussion}

Throughout the experiment, the system maintained a ${ }^{15} \mathrm{~N}_{2}$-enriched atmosphere. The $\mathrm{SF}_{6}$ data indicated, however, 
Fig. 4. The $\delta^{15} \mathrm{~N}$ values of needle, branch, stem, coarse roots (C. root), and fine roots (F. root) of Jeffrey pines, bulk soil (B. soil), and rhizosphere soil (Rh. soil). Eight trees were exposed to ambient $\left[\mathrm{CO}_{2}\right]\left(365 \mu \mathrm{L} \cdot \mathrm{L}^{-1}\right)$ for $78 \mathrm{~d}$, while the remaining eight trees were exposed to elevated $\left[\mathrm{CO}_{2}\right]\left(700 \mu \mathrm{L} \cdot \mathrm{L}^{-1}\right)$. Within each $\mathrm{CO}_{2}$ treatment, four trees were exposed to a ${ }^{15} \mathrm{~N}$-enriched soil atmosphere. The ANOVA results showed no significant main nor interactive effects of the labeling and $\mathrm{CO}_{2}$ treatment $(P<0.05)$. Error bars represent standard errors of the mean $(n=4)$.

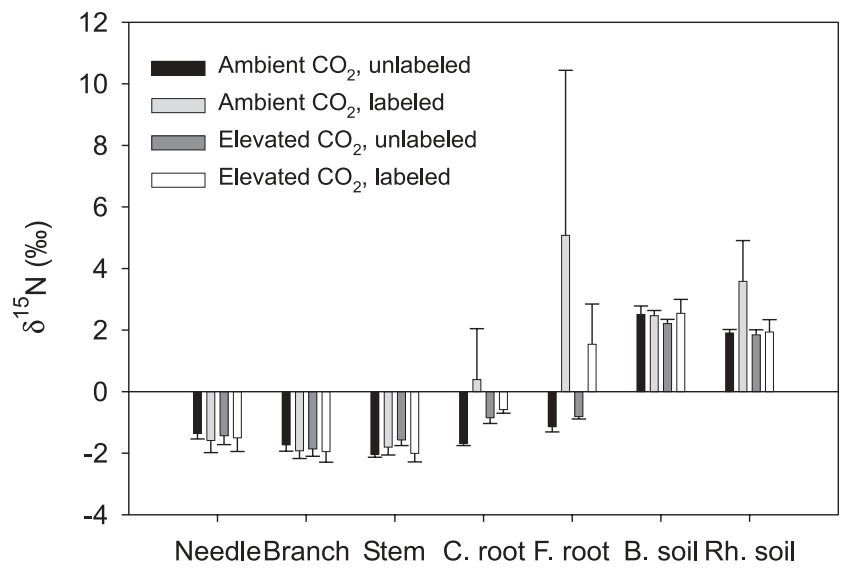

that leaks were present in the system (Fig. 2). The leaks did not have any effects on measurement of relative effects of $\mathrm{CO}_{2}$ treatments, however, because the applied label was exactly the same in each container. Using the $\mathrm{SF}_{6}$ data, we calculated that the total air volume inside the system was $115 \mathrm{~L}$. Since the natural abundance of ${ }^{15} \mathrm{~N}_{2}$ equals $0.366 \%$, the total amount of ${ }^{15} \mathrm{~N}_{2}$ present was $0.42 \mathrm{~L}$. Each time we injected between 0.5 and $1 \mathrm{~L}$ of pure ${ }^{15} \mathrm{~N}$ so initially the ${ }^{15} \mathrm{~N} \%$ was doubled resulting in a $\delta^{15} \mathrm{~N}$ signal between $1000 \%$ and $2000 \%$ (Fig. 2). The $\delta^{15} \mathrm{~N}$ values prior to new additions were never lower than $500 \%$.

The labeling procedure and $\mathrm{CO}_{2}$ treatment did not affect weight, $\mathrm{N}$ content, or $\delta^{15} \mathrm{~N}$ of individual plant parts and soils (Figs. 3, 4, and 5). The results from our ${ }^{15} \mathrm{~N}_{2}$ labeling study support results from other studies, showing that nonsymbiotic $\mathrm{N}_{2}$ fixation is not likely to provide a large input of $\mathrm{N}$ in forest ecosystems (e.g., Barkmann and Schwintzer 1998) and cannot explain large $\mathrm{N}$ accretion rates found in several forest ecosystems (Binkley et al. 2000). In addition, $\mathrm{N}_{2}$ fixation did not increase under elevated $\left[\mathrm{CO}_{2}\right]$. We initially hypothesized, however, that $\mathrm{N}_{2}$ fixation would be stimulated by elevated $\left[\mathrm{CO}_{2}\right]$ through increased belowground labile $\mathrm{C}$ inputs. Since belowground $\mathrm{C}$ inputs did not increase under elevated $\left[\mathrm{CO}_{2}\right]$ (Fig. 5), we cannot accept or reject our initial hypothesis based on the results of this study. Several other studies have shown that elevated $\left[\mathrm{CO}_{2}\right]$ enhances rhizodeposition in a variety of natural and agricultural plant and tree species (Cheng and Johnson 1998; Van Ginkel and Gorissen 1998; Verburg et al. 1998). Microbial immobilization could have prevented uptake of the label by trees (Mulder 1975), but soils did not show any ${ }^{15} \mathrm{~N}_{2}$ enrichment, indicating that no $\mathrm{N}_{2}$ fixation had occurred. Potentially, the $\mathrm{CO}_{2}$ treatment was too short to be able to detect significant increases in belowground $\mathrm{C}$ inputs in these relatively slow-growing trees.

Since this study represented a first attempt using the ${ }^{15} \mathrm{~N}_{2}$ labeling technique, the experiment was compromised by
Fig. 5. Total $\mathrm{C}$ and $\mathrm{N}$ of bulk and rhizosphere soil planted with Jeffrey pines. Eight trees were exposed to ambient $\left[\mathrm{CO}_{2}\right]$ (365 $\mu \mathrm{L} \cdot \mathrm{L}^{-1}$ ) for $78 \mathrm{~d}$, while the remaining eight trees were exposed to elevated $\left[\mathrm{CO}_{2}\right]\left(700 \mu \mathrm{L} \cdot \mathrm{L}^{-1}\right)$. Within each $\mathrm{CO}_{2}$ treatment, four trees were exposed to a ${ }^{15} \mathrm{~N}$-enriched soil atmosphere. The ANOVA results showed no significant main nor interactive effects of the labeling and $\mathrm{CO}_{2}$ treatment $(P<0.05)$. Error bars represent standard errors of the mean $(n=4)$.

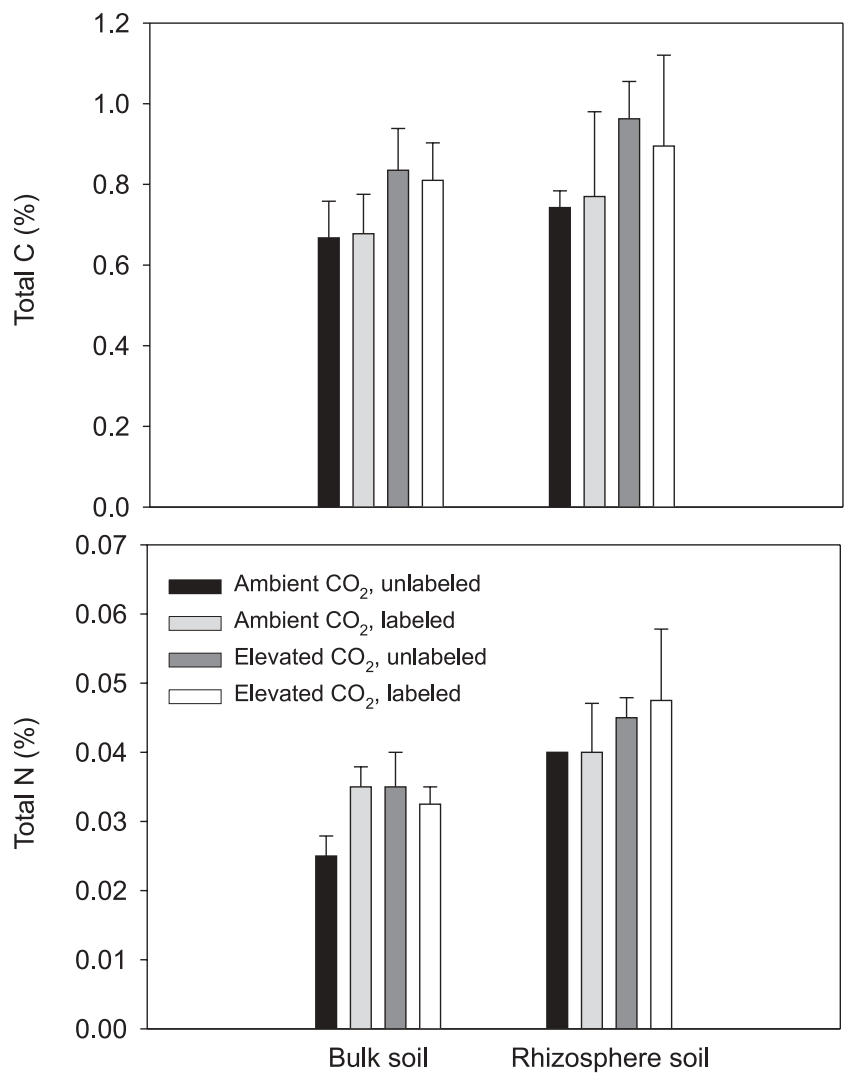

pseudo-replication, a small sample size, and a relatively short duration. Also we did not cover the unlabeled containers, which may have resulted in differences in soil $\left[\mathrm{O}_{2}\right]$, an important parameter affecting nonsymbiotic $\mathrm{N}_{2}$ fixation (Mulder 1975). Still, soils were oxic in both unlabeled and labeled containers, and the ${ }^{15} \mathrm{~N}$ label should have been strong enough to detect fixation of ${ }^{15} \mathrm{~N}_{2}$. The experimental limitations in combination with the high variability observed within each treatment make it difficult to draw firm conclusions from this study. Variability was especially large for the $\delta^{15} \mathrm{~N}$ values of soil and roots of the labeled, ambient $\mathrm{CO}_{2}$ treatment. In this treatment, one tree showed $\delta^{15} \mathrm{~N}$ values of $21.1 \%$, $5.2 \%$, and $7.5 \%$ for the fine roots, coarse roots, and rhizosphere soil, respectively. The fraction of ${ }^{15} \mathrm{~N}$ in this plant originating from $\mathrm{N}_{2}$ fixation $X$ was approximated by the method of Balesdent et al. (1987):

$$
X=\frac{\delta^{15} \mathrm{~N}_{\text {labeled plant }}-\delta^{15} \mathrm{~N}_{\text {unlabeled plant }}}{\delta^{15} \mathrm{~N}_{\text {air }}-\delta^{15} \mathrm{~N}_{\text {unlabeled plant }}}
$$

If we assume that the average $\delta^{15} \mathrm{~N}$ of the labeled air was $500 \%$, and that there is no isotope fractionation during $\mathrm{N}_{2}$ fixation (Nadelhoffer and Fry 1994), the fraction of ${ }^{15} \mathrm{~N}$ 
originated from $\mathrm{N}_{2}$ fixation for fine roots at ambient $\left[\mathrm{CO}_{2}\right]$ was 0.0445 or $4.45 \%$ of total ${ }^{15} \mathrm{~N}$. Multiplying this percentage with the $\mathrm{N}$ content of the fine and coarse roots in this tree resulted in a total amount of $\mathrm{N}_{2}$ fixation of $12.4 \mathrm{mg}$ during the $78 \mathrm{~d}$. This estimate represents an upper limit, since the label was higher than $500 \%$ for most of the time. This overestimation may be partly offset, however, by uptake in favor of the lighter ${ }^{14} \mathrm{~N}$ isotope. The only apparent difference between this tree and all other trees was that the roots showed a high infection with ectomycorrhizal fungi despite the trees not having been inoculated. Although it was just one tree, our results agree with other studies that have found various species of $\mathrm{N}_{2}$-fixing microbes associated with ectoand endo-mycorrhizae (Amaranthus et al. 1990; Li et al. 1992). Further study is needed to determine if the high uptake found in this tree was caused by presence of ectomycorrhizal fungi, or if other factors caused this anomalous result.

Our ${ }^{15} \mathrm{~N}_{2}$ labeling technique appeared promising for measuring $\mathrm{N}_{2}$ fixation rates. At this stage, the experimental limitations and short duration of the study prevented us from drawing firm conclusions with regard to the effects of elevated $\left[\mathrm{CO}_{2}\right]$ on nonsymbiotic $\mathrm{N}_{2}$ fixation, and our initial hypothesis could not be accepted nor rejected. Variability in the ambient $\left[\mathrm{CO}_{2}\right]$ labeled treatment was especially large because of one tree having an abundance of ectomycorrhizal fungi. The described technique promises to be a useful tool to further investigate mechanisms of atmospheric $\mathrm{N}_{2}$ fixation under highly controlled conditions.

\section{Acknowledgements}

Financial support for this study was provided by the Department of Energy. The authors thank E. Sotoodeh for technical assistance.

\section{References}

Aho, P.E., Seidler, R.J., Evans, H.J., and Raju, P.N. 1974. Distribution, enumeration, and identification of nitrogen-fixing bacteria associated with decay in living White fir trees. Phytopathology, 64: 1413-1420.

Amaranthus, M.P., Li, C.Y., and Perry, D.A. 1990. Influence of vegetation type and madrone soil inocolum on associative nitrogen fixation in Douglas-fir rhizospheres. Can. J. For. Res. 20: 368-371.

Arnone, J.A., III, and Gordon, J.C. 1990. Effect of nodulation, nitrogen fixation and $\mathrm{CO}_{2}$ enrichment on the physiology, growth and dry mass allocation of seedlings of Alnus rubra Bong. New Phytol. 116: 55-66.

Balesdent, J., Mariotti. A., and Guillet, B. 1987. Natural ${ }^{13} \mathrm{C}$ abundance as a tracer for studies of soil organic matter dynamics. Soil Biol. Biochem. 19: 25-30.

Barkmann, J., and Schwintzer, C.R. 1998. Rapid $\mathrm{N}_{2}$ fixation in pines? Results of a Maine field study. Ecology, 79: 1453-1457.

Binkley, D., Son, Y., and Valentine, D.W. 2000. Do forests receive occult inputs of nitrogen? Ecosystems, 3: 321-331.

Bormann, B.T., Bormann, F.H., Bowden, W.B., Pierce, R.S., Hamburg, S.P., Wang, D., Snyder, M.C., Li, C.Y., and Ingersoll, R.C. 1993. Rapid $\mathrm{N}_{2}$ fixation in pines, alder, and locust: evidence from the sandbox ecosystem study. Ecology, 74: 583-598.
Bremer, E., Janzen, H.H., and Gilbertson, C. 1995. Evidence against associative $\mathrm{N}_{2}$ fixation as a significant $\mathrm{N}$ source in long-term wheat plots. Plant Soil, 175: 13-19.

Chalk, P.M. 1991. The contribution of associative and symbiotic nitrogen fixation to the nitrogen nutrition of non-legumes. Plant Soil, 132: 29-39.

Cheng, W., and Coleman, D.C. 1990. Effect of living roots on soil organic matter decomposition. Soil Biol. Biochem. 22: 781-787.

Cheng, W., and Johnson, D.W. 1998. Elevated $\mathrm{CO}_{2}$, rhizosphere processes, and soil organic matter decomposition. Plant Soil, 202: $167-174$.

Crawford, R.H., Li, C.Y., and Floyd, M. 1997. Nitrogen fixation in root-colonized large woody residue of Oregon coastal forests. For. Ecol. Manage. 92: 229-234.

Grant, D., and Binkley, D. 1987. Rates of free-living nitrogen fixation in some piedmont forest types. For. Sci. 33: 548-551.

Hendrickson, O.Q. 1990. Asymbiotic nitrogen fixation and soil metabolism in three Ontario forests. Soil Biol. Biochem. 22: 967-971.

Johnson, D.W., and Todd, D.E. 1998. Harvesting effects on long-term changes in nutrient pools of mixed oak forest. Soil Sci. Soc. Am. J. 62: 1725-1735.

Johnson, D.W., Ball, J.T., and Walker, R.F. 1995. Effects of elevated $\mathrm{CO}_{2}$ and nitrogen on nutrient uptake in ponderosa pine seedlings. Plant Soil, 168-169: 535-545.

Johnson, D.W., Ball, J.T., and Walker, R.F. 1997. Effects of $\mathrm{CO}_{2}$ and nitrogen fertilization on vegetation and soil nutrient content in juvenile ponderosa pine. Plant Soil, 190: 29-40.

Li, C.Y., Massicote, H.B., and Moore, L.V.H. 1992. Nitrogen-fixing Bacillus sp. associated with Douglas-fir tuberculate ectomycorrhizae. Plant Soil, 140: 35-40.

Mulder, E.G. 1975. Physiology and ecology of free-living nitrogen-fixing bacteria. In Nitrogen fixation in free-living micro-organisms. Edited by W.P.D. Stewart. Cambridge University Press, Cambridge, UK. pp. 3-28.

Nadelhoffer, K.J., and Fry, B. 1994. Controls on natural nitrogen-15 and carbon-13 abundances in forest soil organic matter. Soil Sci. Soc. Am. J. 52: 1633-1640.

Norby, R.J. 1987. Nodulation and nitrogenase activity in nitrogen-fixing woody plants stimulated by $\mathrm{CO}_{2}$ enrichment of the atmosphere. Physiol. Plant. 71: 77-82.

Oren, R., Ellsworth, D.S., Johnsen, K.H., Phillips, N., Ewers, B.E., Maier, C., Schäfer, K.V.R., McCarthy, H., Hendrey, G., McNulty, S.G., and Katul, G.G. 2001. Soil fertility limits carbon sequestration by forest ecosystems in $\mathrm{CO}_{2}$-enriched atmosphere. Nature (Lond.), 411: 469-472.

Roskoski, J.P. 1980. Nitrogen fixation in hardwood forests of the northeastern United States. Plant Soil, 54: 33-44.

Sims, A.P., Barber, D.J., Folkes, B.F., and Walls, D. 1986. Sealed lysimeters for the direct estimation of dinitrogen fixation by grain legume crops. Plant Cell Environ. 9: 111-119.

Taub, D.R., Seemann, J.R., and Coleman, J.S. 2000. Growth in elevated $\mathrm{CO}_{2}$ protects photosynthesis against high-temperature damage. Plant Cell Environ. 23: 649-656.

Tjepkema, J. 1978. Nitrogen fixation in forests of central Massachusetts. Can. J. Bot. 57: 11-16.

Van Ginkel, J.H., and Gorissen, A. 1998. In situ decomposition of grass roots as affected by elevated atmospheric carbon dioxide. Soil Sci. Soc. Am. J. 62: 951-958.

Verburg, P.S.J., Gorissen, A., and Arp, W.J. 1998. Carbon allocation and decomposition of root-derived organic matter in a plant-soil system of Calluna vulgaris as affected by elevated $\mathrm{CO}_{2}$. Soil Biol. Biochem. 30: 1251-1258. 
Vitousek, P.M., Van Cleve, K., Balakrishnan, N., and Mueller-Dombois, D. 1983. Soil development and nitrogen turnover in montane rainforest soils on Hawaii. Biotropica, 15: 268-274.

Warembourg, F.R. 1993. Nitrogen fixation in soil and plant systems. In Nitrogen isotope techniques. Edited by R. Knowles and T.H. Blackburn. Academic Press, New York. pp. 127-156.
Zak, D.R., Pregitzer, K.S., Curtis, P.S., Vogel, C.S., Holmes, W.E., and Lussenhop, J. 2000. Atmospheric $\mathrm{CO}_{2}$, soil-N availability, and allocation of biomass and nitrogen by Populus tremuloides. Ecol. Appl. 10: 34-46. 